\title{
Flow Coefficients of Doorway Flow Field in Two-room Building Fires
}

\author{
Ju, Hyeon Don* $\cdot$ Kim, Hyun hyi**
}

\begin{abstract}
In the case of a fire of two-room's enclosure, the inflow and outflow mass rates through the doorway located between a burn room and an adjacent room have been researched. The objective of this study are to calculate the flow rates through the doorway of the burn room, to study the inflow and outflow coefficients of the doorway, and accurately to predict the neutral-plane height from the floor of the room in the stratified fire cases of the two-room's enclosure. The inflow and outflow mass rates are analyzed by FDS developed by the National Institute of Standard and Technology, USA. The analyzed results by FDS are compared with the experimental results performed by Nakaya et al. By our study it is known that the flow coefficients vary according to fire size and opening configuration and the mean values of the inflow and outflow coefficients are 0.8 and 1.0 respectively.
\end{abstract}

Key words : Neutral-plane height, Flow coefficient, Doorway, CFD

\section{요 지}

방이 두 개인 경우의 화재에서 화재실과 인접한 실 사이에 위치한 문을 통하여 들어오고, 나가는 질량유량들에 대하여 연구 가 되어 오고 있다. 본 연구의 목적은 화재실의 문을 통한 유량을 계산하고, 그 문에 대한 흡입 및 송출 유량계수들을 연구하 고, 나아가서 2 개의 방을 가진 밀폐공간 화재에서 실의 바닥으로부터 중성대의 높이를 정확히 예측하는데 있다. 미국의 국립표 준기술국에 의해 개발된 FDS 소프트웨어에 의해 흡입 및 송출 유량을 해석하였다. FDS에 의해 해석된 결과들은 Nakaya 등 에 의해 수행된 실험결과들과 비교하였다. 본 연구에 의해 흐름계수들은 화재의 크기와 문의 모양에 따라 변하고, 흡입 및 송 출 유량계수의 평균값은 각각 0.8 과 1.0 임을 알 수 있다.

핵심용어 : 중성대 높이, 흐름계수, 문, 전산유체역학

\section{Introduction}

It is very important in fire protection engineering that the inflow and outflow flow rates through doorways of the rooms are modeled mathematically. The room is only partly filled with hot gases, collected under the ceiling. This model is called two-zone model or stratified case. The two-zone model represents the room consisting of two distinct zones: uniformly distributed hot gas zone, and cooling air zone with ambient temperature. Most doorways are classified as orifices that only a part of doorway area carries the flow efficiently. In applications effective area is typically around $60-70 \%$ of actual doorway area, and this is expressed by flow coefficient.

Kerosene-water experiments on flows through a single window and a single doorway were performed (Prahl and Emmons, 1975). The results indicate that both the inflow and outflow coefficients approach 0.68 as Reynolds number increased. The hydrostatic pressure field within burn room or adjacent room dominates the flow through an opening. At any elevation the mass flow rates through an opening can be calculated as if the opening were a small orifice which does not affect the pressure field (Zukoski and Kubota, 1980). A full-scale fire experiment to investigate flow coefficients through openings was performed (Stekler et al., 1984). The measured flow coefficients of room opening show no significant dependence on the energy release rate of fire source, opening geometry, or the location of the fire source. The mean value of the inflow coefficient is 0.68 and the value of the outflow coefficient 0.73 . Full-scale steady-state fire experiments to investigate the fire-induced flows through doorways connecting the burn room to the adjacent room were performed (Nakaya et al., 1986). The flow velocities through the widest doorway are slow because of the small

\footnotetext{
*Member · Department of Fire \& Disaster Prevention Engineering, International University of Korea, South Korea(E-mail: hdju2433@hanmail.net)

**Member - Department of Fire \& Disaster Prevention Engineering, International University of Korea, South Korea
} 
temperature difference between inside and outside of the doorway. The velocities cause poor mixing. The vertical temperature profile in the burn room is not uniform as for the narrow openings. In the narrow openings, the vertical temperature profile seems to be uniform and the new inflow coefficient was determined as 0.64 . The flows through a ceiling or floor vertical vent were described as the flow caused by pressure difference plus an exchange flow based on the density difference of gases (Yao et al., 1999). As the fire-strength became larger, the air mass flow rate through the doorway was observed to increase and the average hotlayer temperature also was observed to increase but the doorway neutral-plane height was observed to decrease (Jeong and Ryou, 2002). Considering a constant density of the hot gas layer in a burning room, the flow coefficient of the buoyancy driven fire gases flowing through a door is 0.68 (Emmons, 2002). The cooling performance of a designed enclosure model is checked by numerical thermal flow analysis with a computational fluid dynamics (CFD) code FLUENT (Ju et al., 2004). Correlation equations of mass flow rates proposed by Nakaya et al. were studied numerically with FDS (Nakaya et al., 1986; Chow and Zou, 2005). Results analyzed by Chow and Zou are similar to experimental results deduced by Nakaya et al.. The airflow of the two-room's enclosure was analyzed by the various CFD (Stavrakakis and Markatos, 2009). The performances of the turbulence models using correlation equations proposed by Nakaya et al. and Chow and Zou were tested. The mean velocity field across the width of the doorway provided by Stereoscopic particle image velocimetry (SPIV) was displayed (Bryant, 2009). In the two-enclosure model consisting with a left-hand room, a doorway and a righthand corridor, transient ceiling jet velocities flowing through the unconfined corridor ceiling have been studied $(\mathrm{Ju}$, 2012).

In well ventilated cases, the outflow mass flow rate through the doorway is more or less equal to the inflow rate, but the outflow rate is unequal to the inflow rate in stratified fire cases. Thus, the objective of this study are (1) to calculate the inflow and outflow mass rates through the doorway of the burn room, (2) to study the inflow and outflow coefficients of the doorway, and (3) accurately to predict neutral-plane height which the pressures between inside and outside of the doorway are the same in the stratified fire cases when the fire in the two-room's enclosure happens. Therefore this study presents the 2-dimensional velocity and pressure contours along the centerline of the burn room doorway. And the neutral-plane height at the doorway was used when the inflow and outflow mass rates through the doorway were calculated. The inflow and outflow rates calculated by the FDS will be used if the inflow and outflow coefficients are inserted in the various mass flow rate equa- tions reported in the literature. Therefore the inflow and outflow coefficients of various mass flow rates equations are accurately calculated (Nakaya et al., 1986; Karlsson and Quintiere, 2000; Quintiere, 2006).

\section{Calculation of Flows through Doorway of Two-room Enclosure}

\subsection{Background}

The geometry of the two-room's enclosure model is illustrated in Fig. 1. The left-hand room that contains a fire source is named "burn room" and the right-hand room is named "adjacent room". The fire source is enclosed by the surrounding walls of the burn room and a doorway is located between the burn room and the adjacent room. The primary source of cooling air entrainment is the fire plume which acts as a pump to move the cooling air up into the ceiling. As the fire develops and continues to burn, the accumulation of heat causes the air temperature in the upper region of the burn room to rise. The density of the upper region decreases due to the increasing air temperature. If the temperature and pressure of the adjacent room remain almost constant at their respective initial conditions, positive hydro-pressure difference which is between two room upper regions can become large in eventually driving the hot gas of the burn room and spreading the gas into the adjacent room (Emmons, 2002).

As shown in Fig. 1 for two-room's fires, the fire source burns at the center of the burn room. The hot gas which is heated by the fire source is driven by buoyancy and the development of an upward turbulent flow transfers the hot gas into the upper region of the room. The presence of the wall boundaries and the soffit of the room create a "reservoir" for the accumulation of the hot gases below the ceiling, which is commonly referred as the "hot air layer" region. While the hot gases accumulate in the upper region, cooling air from the surrounding is entrained into the two rooms through two doorways to supply oxygen to the fire in the burn room. This cooling air represents the "cooling air layer" region of the two rooms. The two-layer flow type of enclosure fires is a special feature and is called the stratified cases. The height from the floor to the two-layer interface is considered as an important measured datum in fire experiment. As this interface continues to the level below the

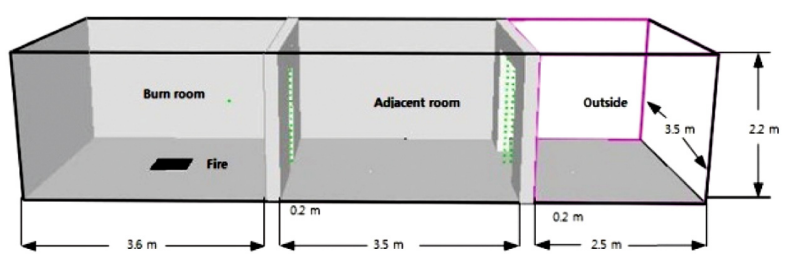

Fig. 1. Geometry of two-room's enclosure model 


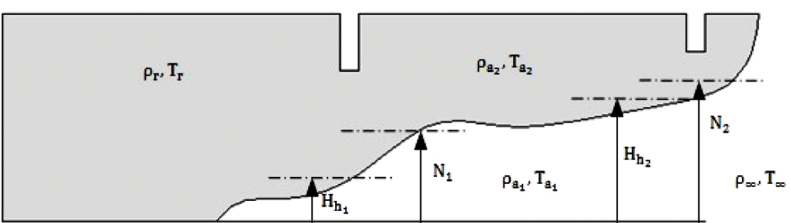

Fig. 2. Schematic diagram of two-room's enclosure fire

depth of the soffit, the amount of hot gases exceeds the volume of the smoke reservoir. The schematic diagram of smoke spread and cooling air entrainment is presented in Fig. 2. The one doorway is located between the burn room and the adjacent room and the other doorway is located between the adjacent room and surroundings. Throughout the course of real fires, absolute static pressure differences at the doorways are almost neglected. But hydrostatic pressure differences at the doorways are large enough to drive a significant exchange between hot air and cooling air.

In the fire modeling of this study, large eddy simulation is applied to examine the inflow and outflow rates through the doorways of the burn room and the adjacent room. The tworoom's enclosure results examined by Nakaya et al. are adopted as the experimental results of this study. In addition to the temperatures measured by aspirated thermocouples and the velocities by bi-directional probe at the doorways, the mass flow rate, the neutral-plane height and the thickness of the hot layer were also adopted. The experimental results are compared with the analytical results of numerical simulations (Nakaya et al., 1986) .

The Numerical simulations are performed through the FDS (Version 5.3) computer code developed by NIST. The FDS is a Computational Fluid Dynamics (CFD) model of fire-driven fluid flow. The FDS solves numerically a form of the Navier-Stokes equations appropriate for low-speed, thermally-driven flow with an emphasis on smoke and heat transport from fires. The partial derivatives of the conservation equations of mass, momentum, and energy are approximated by the finite difference method. Turbulent motions are separated into large and small eddy motions in LES. Turbulent eddies that account for most of the large scale motion are large enough to be calculated with sufficient accuracy from the equations of the fluid mechanics. Therefore motion of large eddies is simulated directly, but the small-scale eddy motion is approximated by means of the Smagorinsky form. Two combustion models are used in the FDS. Diffusion of fuel and oxygen are modeled directly for DNS with global one-step, finite-rate chemical reaction. The model is based on the assumption that the combustion is mixing-controlled and that the reaction of fuel and oxygen is infinitely fast (McGrattan et al., 2009; Guan and Kwok, 2009).

The schematic drawing of the computational geometry is shown in Fig. 3, which has been made possible by Smoke-

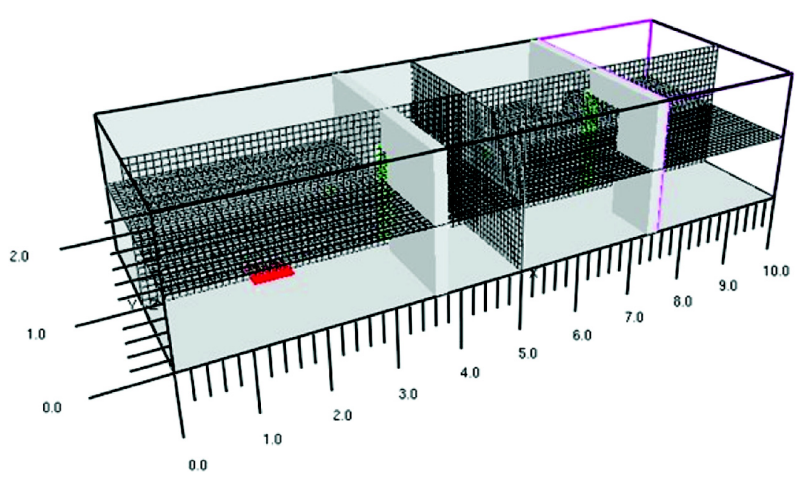

Fig. 3. Grid distribution used in numerical simulations

view, a post-processor graphical-user-interface application (Forney, 2008).

\subsection{Various Equations for Doorway Flow}

By the experiments of Nakaya et al., the uniform temperature was formed in the hot layer of the burn room, and the nearly uniform temperatures were also formed in the hot and cold layers of the adjacent room. The following expressions on the mass flow rate through the doorway connecting the rooms were presented from their experimental results.

The mass outflow rate $\left(\dot{m}_{g}\right)$ and inflow $\operatorname{rate}\left(\dot{m}_{a}\right)$ at the doorway located between the burn room and the adjacent room are

$$
\begin{aligned}
& \dot{m}_{g}=C_{o} \cdot W \cdot \rho_{\infty} \cdot T_{\infty} \cdot \sqrt{\frac{2 g}{T_{R}}} \cdot\left(\dot{M}_{g 1}+\dot{m}_{g 2}\right), \\
& \text { where } \dot{m}_{g 1}=\left(\frac{1}{T_{a_{1}}}-\frac{1}{T_{r}}\right)^{1 / 2} \cdot\left(H_{h_{2}}-H_{N_{1}}\right)^{3 / 2} \text { and } \\
& \dot{m}_{g 2}=\frac{2}{3}\left(\frac{1}{T_{a_{2}}}-\frac{1}{T_{r}}\right)^{-1}\left[\left[\left(\frac{1}{T_{a_{1}}}-\frac{1}{T_{r}}\right)\left(H_{h_{2}}-H_{N_{1}}\right)+\right.\right. \\
& \left.\left.\qquad\left(\frac{1}{T_{a_{2}}}-\frac{1}{T_{r}}\right)\left(H_{o}-H_{h_{2}}\right)\right]^{3 / 2}-\left[\left(\frac{1}{T_{a_{1}}}-\frac{1}{T_{r}}\right)\left(H_{h_{2}}-H_{N_{1}}\right)\right]^{3 / 2}\right] \\
& \dot{m}_{a}=\frac{2}{3} C_{i} \cdot \rho_{\infty} \cdot T_{\infty} \cdot W \cdot H_{o}^{3 / 2} \cdot \sqrt{2 g} \cdot \frac{1}{T_{a_{1}}}\left(1-\frac{T_{a_{1}}}{T_{r}}\right)^{1 / 2}\left(\frac{H_{N_{1}}}{H_{o}}\right)^{3 / 2}
\end{aligned}
$$

$C_{o}$ is the outflow coefficient, $C_{i}$ is the inflow coefficient, $W$ is the doorway width, $H_{o}$ is the doorway height, $\rho_{\infty}$ is the ambient air density, $T_{\infty}$ is the ambient temperature, $g$ is gravity acceleration, $T_{r}$ is the temperature of the hot air layer in the burn room, $T_{a_{1}}$ is the temperature of the cold air layer in the adjacent room, $T_{a_{2}}$ is the temperature of the hot air layer in the adjacent room, $H_{h_{2}}$ is the height of the boundary between the hot and cold layers at the doorway located between the adjacent room and ambient, which is almost equal to the height of the boundary between the hot and cold layers inside the adjacent room, and $H_{N_{1}}$ is the neutralplane height from the floor at the doorway located between the burn room and the adjacent room (Nakaya et al., 1986).

A room is only partly filled with hot gases, collected 
under the ceiling. This room fire model is called the twozone model or the stratified case (Karlsson and Quintiere, 2000; Quintiere, 2006). Therefore the hot gases flow out through the top of the opening and flesh air enters through the lower part of the opening. The mass outflow rate $\left(\dot{m}_{g}\right)$ and inflow rate $\left(\dot{m}_{a}\right)$ at the doorway located between the burn room and the adjacent room are

$$
\begin{aligned}
& \dot{m}_{g}=\frac{2}{3} C_{o} \cdot \rho_{\infty} \cdot T_{\infty} \cdot \sqrt{2 g} \cdot W \cdot H_{o}^{3 / 2} \cdot \frac{1}{T_{a_{1}}} \cdot \sqrt{\frac{T_{a_{1}}}{T_{r}}\left(1-\frac{T_{a_{1}}}{T_{r}}\right)}\left(1-\frac{H_{N_{1}}}{H_{o}}\right)^{3 / 2} \\
& \dot{m}_{a}=\frac{2}{3} C_{i} \cdot \rho_{\infty} \cdot T_{\infty} \cdot \sqrt{2 g} \cdot W \cdot H_{o}^{3 / 2} \cdot \frac{1}{T_{a_{1}}} \cdot \sqrt{1-\frac{T_{a_{1}}}{T_{r}}} \\
& \left(\frac{H_{N_{1}}}{H_{o}}-\frac{H_{h_{1}}}{H_{o}}\right)^{1 / 2} \cdot\left(\frac{H_{N_{1}}}{H_{o}}+\frac{1}{2} \frac{H_{h_{1}}}{H_{o}}\right)
\end{aligned}
$$

where $H_{h_{1}}$ is the height of the boundary between the hot and cold layers at the doorway located between the burn room and the adjacent room (Quintiere, 2006).

\subsection{Mass Inflow and Outflow Rate Calculated by FDS}

In the FDS (McGrattan et al., 2009), the pressure is decomposed into a "background" pressure and a perturbation. The pressure within the $m$-th enclosure, for example, is linear combination of its background pressure meant hydrostatic pressure field and flow-induced pressure perturbation meant static pressure field:

$$
p(\vec{x}, t)=\bar{p}_{m}(z, t)+\tilde{p}(\vec{x}, t)
$$

where $\bar{p}_{m}(z, t)$ and $\tilde{p}(\vec{x}, t)$ are the background pressure and the flow-induced pressure perturbation, respectively, and $\vec{x}$ is spatial co-ordinate. The background pressure is a function of the vertical spatial coordinate, $z$ and time. For most of enclosure fire application, the background pressure changes little according with height or time. However, for situations where an enclosure is very well sealed or little high, the background pressure is taken into account. In the FDS (McGrattan et al., 2009), the ambient pressure field is denoted $\bar{p}_{0}(z)$. The purpose of decomposing the pressure is that for low-Mach number flows it can be assumed that the temperature and density are inversely proportional, and thus the equation of state (the ideal gas law) in the $m$-th enclosure can be approximated.

$$
\bar{p}_{m} M=\rho R_{o} T
$$

where $\bar{p}_{m}$ is the pressure within the $m$-th enclosure, $M$ is the molecular weight of the gas, $\rho$ is the density, $T$ is the temperature and $R_{o}$ is the ideal gas constant, $8.314 \mathrm{~kJ} /(\mathrm{K} \cdot \mathrm{kmlo})$. In a small enclosure, we perhaps use the value of the standard atmospheric pressure, $101.3 \mathrm{kPa}$ because the hydrostatic pressure varies little. The molecular weight of air is approximately $28.9 \mathrm{~kg} / \mathrm{kmol}$; this value can also be used for fire gases, since to the greatest extent these consist of the air. The Eq. (6) becomes

$$
T=\frac{353}{\rho}
$$

where the units of $T$ and $\rho$ are given in $[K]$ and $[\mathrm{kg} /$ $\mathrm{m}^{3}$ ], respectively.

The equation of the stratification in the background pressure field is derived as shown as

$$
\frac{d \bar{p}_{m}}{d z}=-\rho_{m}(z) g
$$

where $\rho_{m}$ is the background density.

The fire of the burn room could increase the background pressure. The mass flow rate $(\dot{m})$ across a certain height $\mathrm{z}$ of the vents above the neutral-plane is given by

$$
\dot{m}(z)=C_{d} \int_{0}^{z} W \cdot \rho_{m}(z) \cdot V(z) d z
$$

where $C_{d}$ is the flow coefficient.

Applying Bernoulli's equation and Eq. (7), the velocity can be written as the function of a pressure difference in height $\mathrm{z}$ above the neutral-plane:

$$
V(z)=\sqrt{\frac{2|\Delta p(z)|}{\rho_{m}(z)}}
$$

where $|\Delta p(z)|$ is the absolute value of the pressure difference, which is a function of the height $z$ above the neutral-plane, and $\rho_{m}(z)$ is the density as function of height $z$ from the floor at the doorway in $m$-th enclosure.

Using Eqs. (7), (9) and (10), the mass flow rate of hot gases flowing out through the doorway of the burn room can be written as

$$
\dot{m}_{g}=C_{d} \cdot \int_{0}^{z} W \sqrt{2 \cdot \rho_{m}(z) \cdot|\Delta p(z)|} d z
$$

For large openings, $\Delta p$ is perhaps assumed to be the difference of the hydrostatic pressure, where the velocity is typically in the range of $1-5 \mathrm{~m} / \mathrm{s}$, and the Reynolds Number is in the vicinity of $10^{6}, C_{d}$ is a little larger than 0.6. And for small openings, $\Delta p$ is assumed to be the difference of static pressure. But in a little large doorways and windows, the pressure difference is meant to be the difference of the combination pressure of the hydrostatic pressure component and the static pressure component. The static pressure con- 
tribution to the pressure difference will be considered significantly in the evaluation of the mass flow rate of gases flowing out.

The outflow mass rate from the burn room through the doorway may be calculated by Eq. (11). This can be achieved numerically by the summation of $\sqrt{2 \cdot \rho_{m}(z) \cdot|\Delta p(z)|}$ in each height thickness $(\Delta z)$ in $z$ direction, as follows:

$$
\dot{m}_{g}=C_{o} \cdot \sum_{i=1}^{n} \sqrt{2 \cdot \rho_{m}\left(z_{i}\right) \cdot\left|\Delta p\left(z_{i}\right)\right|} \cdot W \cdot \Delta z
$$

where $n$ is the number of outflow grids at the $z$ above neutral-plane height and $C_{o}$ is the outflow coefficient.

Also, the inflow mass rate to the burn room through the doorway may be calculated. This can be achieved numerically by the summation of $\sqrt{2 \cdot \rho_{m}(z) \cdot|\Delta p(z)|}$ in each height thickness $(\Delta z)$ in $\mathrm{z}$ direction, as follows:

$$
\dot{m}_{a}=C_{i} \cdot \sum_{i=1}^{1} \sqrt{2 \cdot \rho_{m}\left(z_{i}\right) \cdot\left|\Delta p\left(z_{i}\right)\right|} \cdot W \cdot \Delta z
$$

where 1 is the number of inflow grids at the $z$ below neutral-plane height and $C_{i}$ is the inflow coefficient.

Utilizing the results analyzed by FDS, the outflow flow coefficient is $\dot{m}_{g}$ divided by $\sum_{i=n}^{1} \sqrt{2 \cdot \rho_{m}\left(z_{i}\right) \cdot\left|\Delta p\left(z_{i}\right)\right|} \cdot W \cdot \Delta z$ and the inflow flow coefficient $\dot{m}_{a}$ divided by $\sum_{i=1}^{1}$ $\sqrt{2 \cdot \rho_{m}\left(z_{i}\right) \cdot\left|\Delta p\left(z_{i}\right)\right|} \cdot W \cdot \Delta z$.

\section{Numerical Analysis and Results}

It were performed the experiments of fire-induced doorway flow in the two-room's enclosure by Nakaya et al.. A burn room was of length $3.55 \mathrm{~m}$, width $3.45 \mathrm{~m}$ and height $2.12 \mathrm{~m}$. And an adjacent room was of length $3.34 \mathrm{~m}$, width $3.45 \mathrm{~m}$ and height $2.17 \mathrm{~m}$ (Nakaya et al., 1986).

In simulation trials, the burn room was of length $3.6 \mathrm{~m}$, width $3.5 \mathrm{~m}$ and height $2.2 \mathrm{~m}$, and the adjacent room of length $3.5 \mathrm{~m}$, width $3.5 \mathrm{~m}$ and height $2.2 \mathrm{~m}$ as shown in Fig. 1. These rooms were connected by the doorway opening of height $1.6 \mathrm{~m}$ which could be varied in width. The adjacent room had the wide fixed doorway opening of width $1.8 \mathrm{~m}$ and height $1.8 \mathrm{~m}$ to a large ambient space. Numerical experiments were conducted for different opening widths of 89 , 59,44 and $29 \mathrm{~cm}$ of doorways connecting the two rooms. A square diffusion burner supplied with propane of size $60 \mathrm{~cm} \times 60 \mathrm{~cm}$ was used as the fire source. The burner was located at the center of the burn room. The propane gas of the burner was supplied at the rates of 50,100, 150, 200, 250, 300 and $350 \mathrm{l} / \mathrm{min}$, which are corresponded to the heat release rates of $86,171,257,342,428,514$ and $600 \mathrm{~kW}$ because the heat of combustion of propane at $25^{\circ} \mathrm{C}$ is about $2044 \mathrm{~kJ} / \mathrm{mol}(=46.45 \mathrm{~kJ} / \mathrm{g}$ ), respectively(Nakaya et al., 1986; Chow and Zou, 2005).

As shown in Fig. 3, the minimum grid size of $0.1 \mathrm{~m}$ was used in simulations. A three-dimensional Cartesian coordinates were assigned with $x, y, z$. The numbers of cells along $x, y$ and $z$ directions are $100(36+2+35+2+25), 36$ and 24 , respectively. Therefore the total number of the cells is $86400(=100 \times 36 \times 24)($ Chow and Zou, 2005).

The boundary conditions for the room walls are assumed to be thermally insulated and ambient temperature and pressure are $20^{\circ} \mathrm{C}$ and $101.325 \mathrm{kPa}$, respectively. Environmental space is extended $2.5 \mathrm{~m}$ outside the adjacent room. In the space, zero gradients for velocity and temperature are given, and pressure also given the ambient pressure (Chow and Zou, 2005).

The simulation results at 40 minutes after the fire occurrence of $342 \mathrm{~kW}$ according to the numbers of cells such as $86,400(=100 \times 35 \times 22), 172,800(=200 \times 35 \times 22), 172,800$

(a)

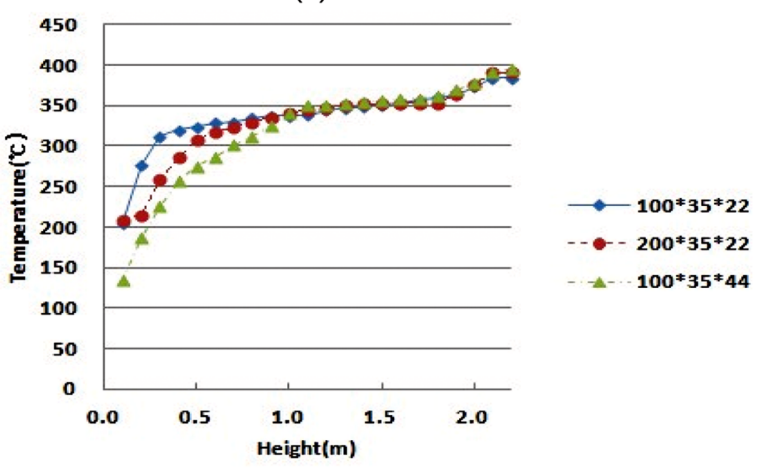

(b)

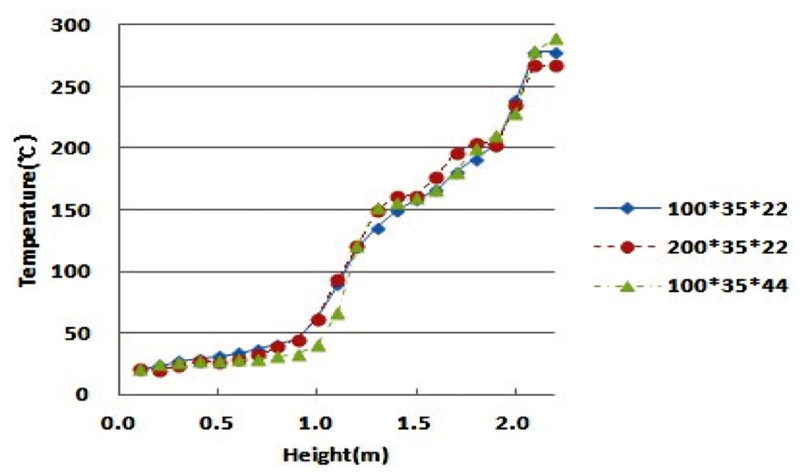

(c)

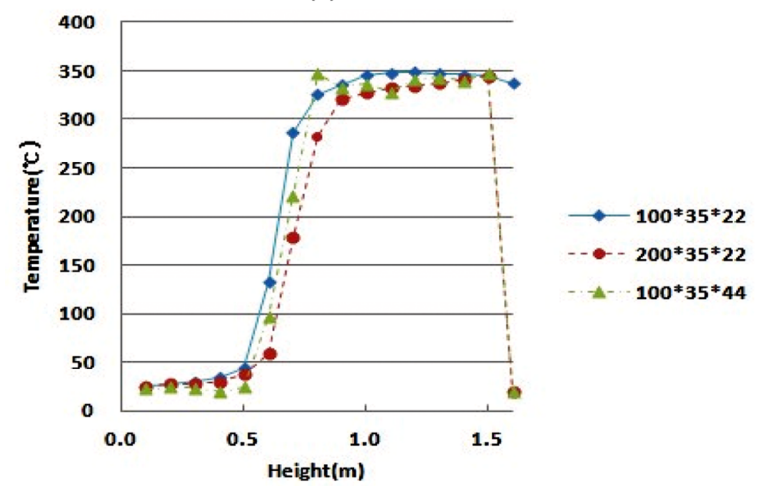

Fig. 4. Comparison of temperatures according to numbers of cells. (a) burn room; (b) adjacent room; (c) doorway of burn room 
$(=100 \times 35 \times 44)$ are shown in Fig. 4. In the midpoint locations of the floor of the burn room, the adjacent room and the doorway of the burn room, the vertical temperature profiles of the three cases are compared. It is known that the data of the three cases are almost similar but the case of 86400 of the burn room is higher than the other cases because of the complicated flow of the burn room.

At 40 minutes after fire occurrence, the simulation results of the three fire sizes of $86 \mathrm{~kW}, 342 \mathrm{~kW}$ and $600 \mathrm{~kW}$ are shown in Fig. 5, respectively. The results predicted by FDS for $86 \mathrm{~kW}$ and $600 \mathrm{~kW}$ almost agreed with the experiment data. But for the $342 \mathrm{~kW}$ fire as in Fig. 5(b), only the temperature of the adjacent room agreed with the experiments. For $600 \mathrm{~kW}$ fire as in Fig. 5(c), it is known that the temperatures of the burn room and the doorway of the burn room agreed with the experiments by Nakaya et al., but are unlike

(a)

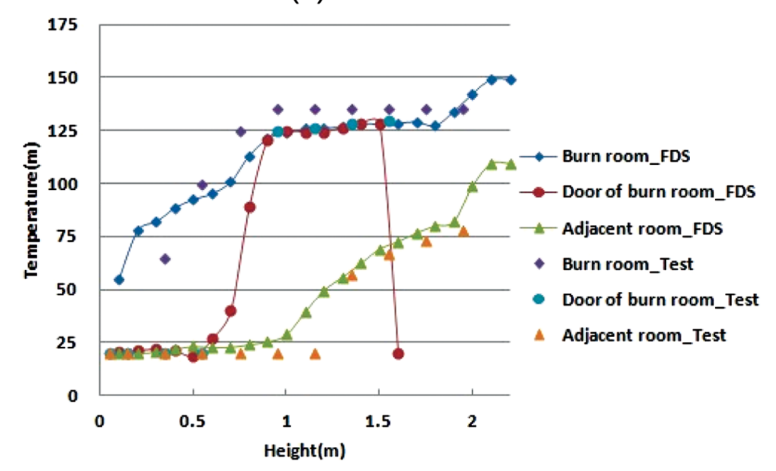

(b)

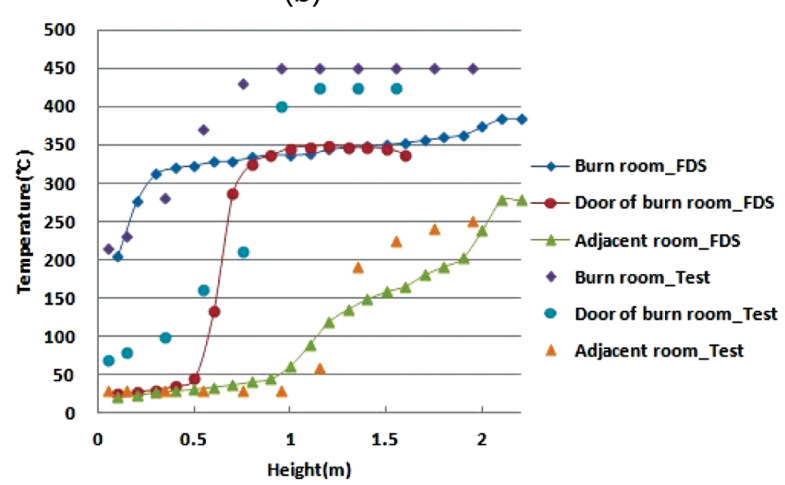

(c)

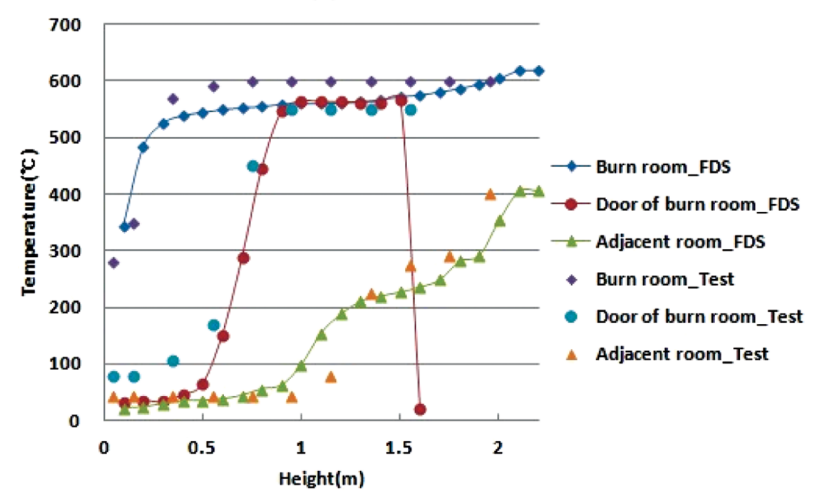

Fig. 5. Vertical temperatures for doorway width $0.59 \mathrm{~m}$ and height $1.6 \mathrm{~m}$. (a) $86 \mathrm{~kW}$; (b) $342 \mathrm{~kW}$; (c) $600 \mathrm{~kW}$ fire to the results of Chow and Zou.

In Table 1, the case of heat output $428 \mathrm{~kW}$ is considered as an example. The doorway of the burn room is width 0.59 $\mathrm{m}$ and height $1.6 \mathrm{~m}$. The parameters shown are expressed by Fig. 2. At 15 minutes after fire occurrence, the outflow mass rate, $0.61 \mathrm{~kg} / \mathrm{sec}$, is unequal to the inflow rate, 0.55 $\mathrm{kg} / \mathrm{sec}$. The outflow mass rate is unequal to the inflow rate in stratified fire cases, but in well ventilated cases more or less equal to the inflow rate. It is assumed that the stratified fire cases occur at about 15 minutes. The predicted upper region temperature of the burn room is lower than the experimental value by Nakaya and Tanaka.

Temperatures in the burn room and doorway 1 (the doorway of the burn room to the adjacent room) are predicted as shown in Fig. 6. As shown in Table 1 and Fig. 6, at 20 minutes after fire occurrence predicted upper region temperature of the burn room, $592 \mathrm{~K}$ is unequal to the temperature experimented by Nakaya and Tanaka,742 K. And temperatures in the adjacent room and doorway 2 (the doorway of the adjacent room to ambient) are also predicted as shown in Fig. 7. As shown in Table and Fig. 7, at 15 minutes after fire occurrence predicted upper region temperatures of the adjacent room is $415 \mathrm{~K}$ (Nakaya et al, 1986).

Table 1. Numerical analysis results (428 kW fire with doorway width $0.59 \mathrm{~m}$ and height $1.6 \mathrm{~m}$ ).

\begin{tabular}{|c|c|c|c|c|c|c|}
\hline \multicolumn{2}{|c|}{ Time(min) } & 10 & 15 & 20 & $\begin{array}{l}\text { Measured by } \\
\text { Nakaya \& } \\
\text { Tanaka }\end{array}$ & $\begin{array}{c}\text { FDS by } \\
\text { Chow \& Zou }\end{array}$ \\
\hline \multicolumn{2}{|c|}{$T_{r}(\mathrm{~K})$} & 563 & 581 & 592 & 742 & - \\
\hline \multicolumn{2}{|c|}{$T_{a_{1}}(\mathrm{~K})$} & 295 & 294 & 295 & 300 & - \\
\hline \multicolumn{2}{|c|}{$T_{a_{2}}(K)$} & 418 & 415 & 435 & - & - \\
\hline \multicolumn{2}{|c|}{$H_{h_{1}}(\mathrm{~m})$} & 0.45 & 0.51 & 0.59 & - & - \\
\hline \multicolumn{2}{|c|}{$H_{h_{2}}(\mathrm{~m})$} & 1.18 & 1.14 & 1.16 & 1.35 & - \\
\hline \multirow{2}{*}{$\begin{array}{c}M \\
(\mathrm{~kg} / \mathrm{sec})\end{array}$} & $M_{g}$ & 0.57 & 0.61 & 0.62 & \multirow{2}{*}{0.59} & \multirow{2}{*}{0.58} \\
\hline & $M_{a}$ & 0.55 & 0.55 & 0.65 & & \\
\hline \multicolumn{2}{|c|}{$N_{1}(\mathrm{~m})$} & 0.7 & 0.85 & 0.87 & 0.67 & 0.72 \\
\hline \multicolumn{2}{|c|}{$N_{2}(\mathrm{~m})$} & 1.3 & 1.28 & 1.28 & - & - \\
\hline
\end{tabular}

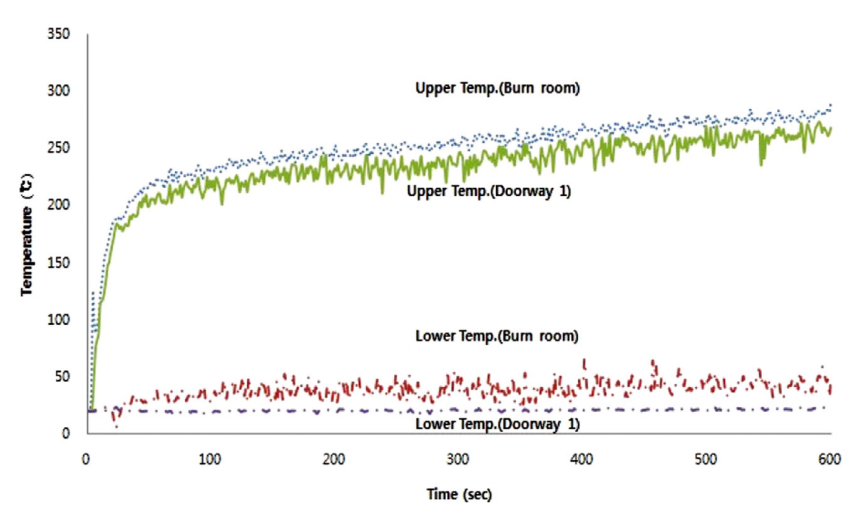

Fig. 6. Various temperatures of the burn room along time in ${ }^{\circ} \mathrm{C}$ 


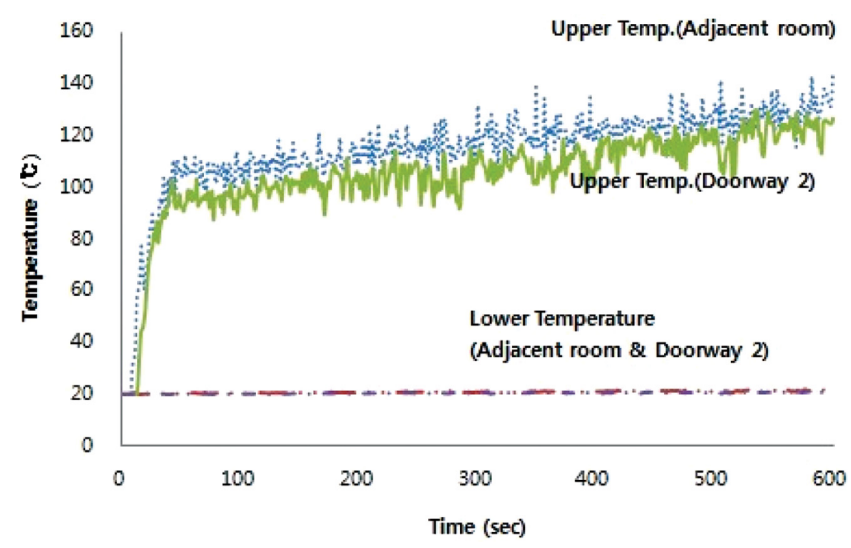

Fig. 7. Various temperatures of the adjacent room along time in ${ }^{\circ} \mathrm{C}$

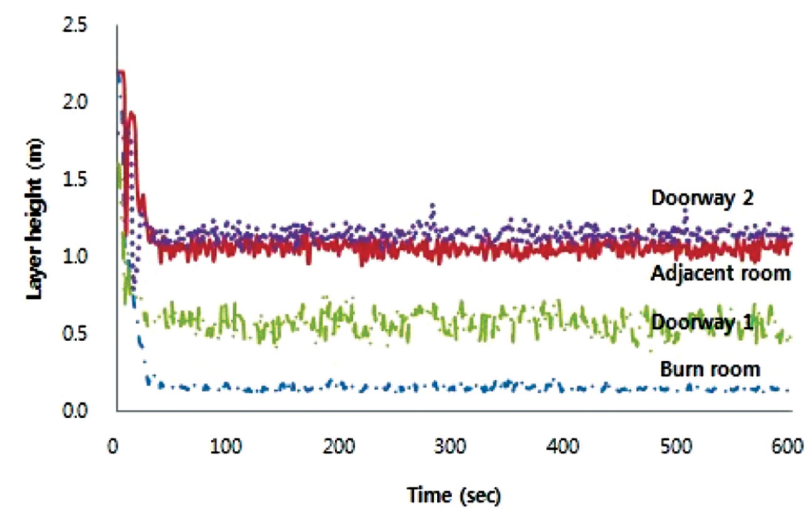

Fig. 8. Heights of the boundaries located between the hot and cold layers in burn room

As shown in Fig. 8, the heights of the interface between the hot layer and the cold layer are predicted in the burn room, the doorway 1 , the adjacent room and the doorway 2 , respectively. The velocity and pressure contours for heat output of $428 \mathrm{~kW}$ are displayed along the centerline of the doorway 1 of width $0.59 \mathrm{~m}$ and height $1.6 \mathrm{~m}$ as shown in Figs. 9 and 10. As shown in Fig. 9, the units of the velocity contours are $\mathrm{m} / \mathrm{sec}$, and the contours of about zero velocity are observed around $0.7 \mathrm{~m}$ from the floor. And as shown in Fig. 10, the pressure differences of the combination pressure of the hydrostatic component and the flow-induced pressure perturbation are displayed, and the units of the pressure contours are $\mathrm{Pa}$. It is observed that the zero pressure differences are located at about $0.85 \mathrm{~m}$ from the floor at 15 minutes after fire occurrence.

As shown in Table 2, numerical analysis results considering various doorway widths and heat release rates are compared with experimental results. The inflow and outflow mass rates through the doorway 1 obtained by the FDS solution are also compared with the experimental flow rates performed by Nakaya and Tanaka. And the numerical results were utilized when the inflow and outflow coefficients of Eqs. (1), (2), (3), (4), (12) and (13) were calculated. The numerical results about the neutral-plane heights are bigger than the measured results (Nakaya et al, 1986).

As shown in Table 3, the flow coefficients vary according to fire size and opening configuration. The mean values of the inflow and outflow coefficients are 0.80 and 1.02 respectively. According to a full-scale study of fire-induced flows through openings performed by Steckler et al., the mean value of the inflow coefficient is 0.68 and the value of the outflow coefficient 0.73 . The inflow coefficient solved by the experimental results by Nakaya et al. is approximately 0.64. But utilizing the numerical results by FDS and the mass flow rates equations proposed by Nakaya et al., the mean values of the inflow and outflow coefficients are 0.54
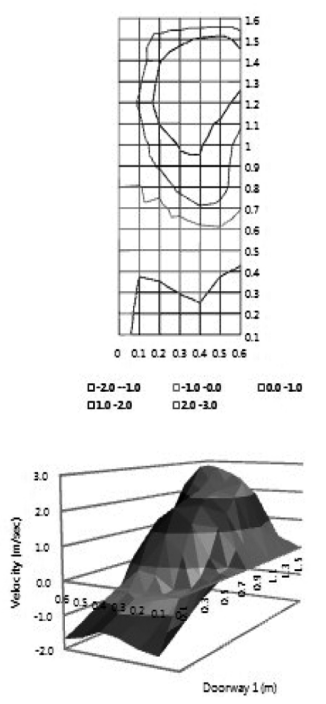

(a)
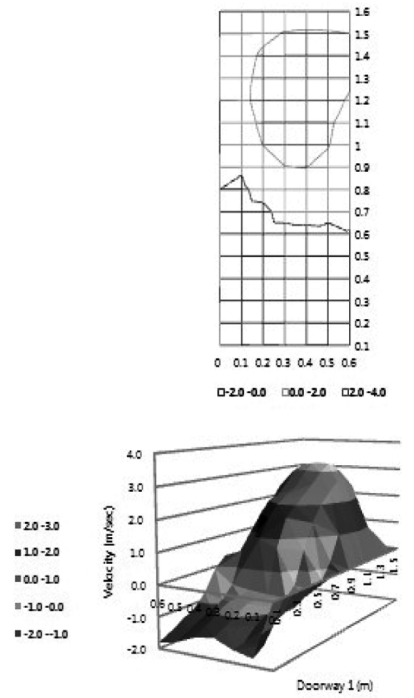

(b)
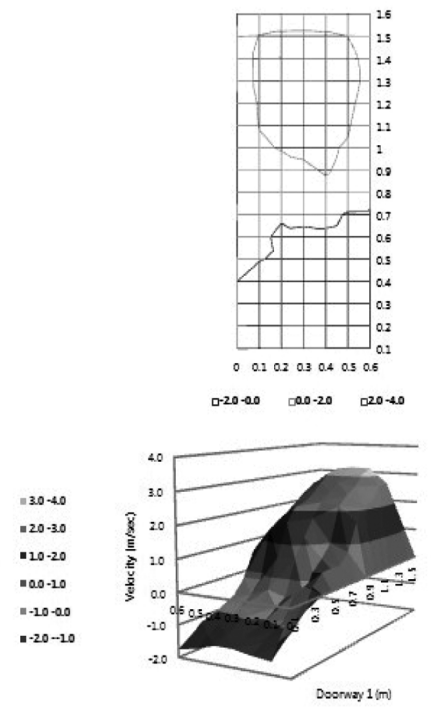

(c)

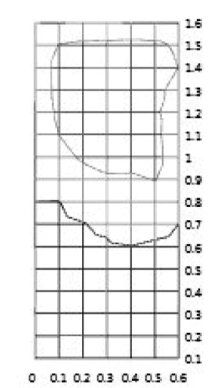

$0-20-20 \quad 000-20 \quad 020-40$
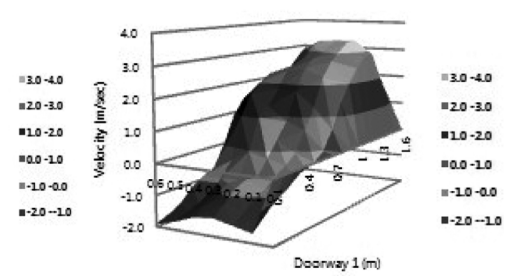

(d)

Fig. 9. Typical results of the velocity contours along the center line of doorway 1 of width $0.59 \mathrm{~m}$ and height $1.6 \mathrm{~m}$ in $\mathrm{m} / \mathrm{sec}$ (a) 300 $\mathrm{s}(5 \mathrm{~min}) ;($ b) $600 \mathrm{~s}(10 \mathrm{~min}) ;(\mathrm{c}) 900 \mathrm{~s}(15 \mathrm{~min}) ;(\mathrm{d}) 1200 \mathrm{~s}(20 \mathrm{~min})$ 


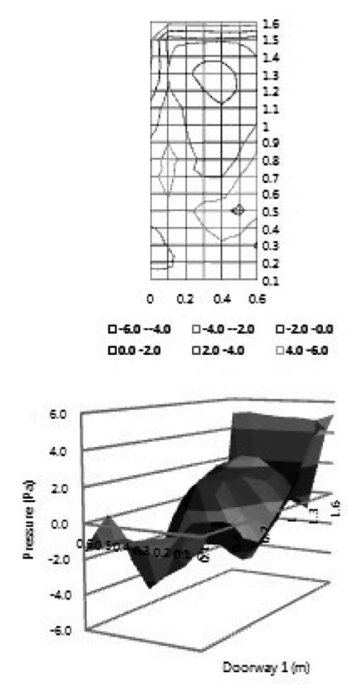

(a)

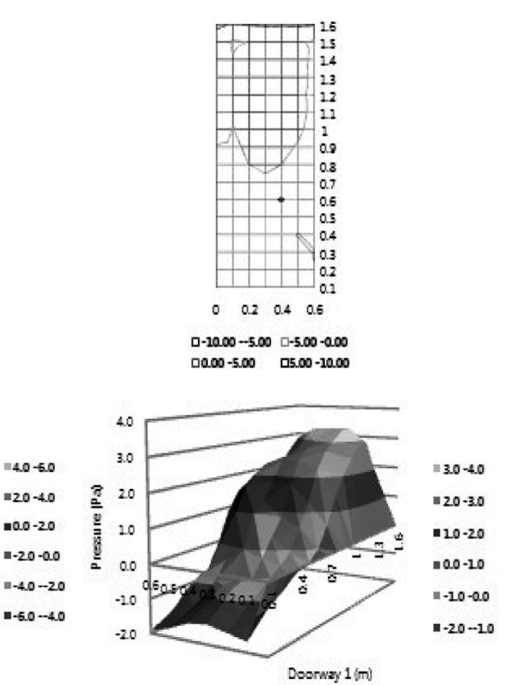

(b)
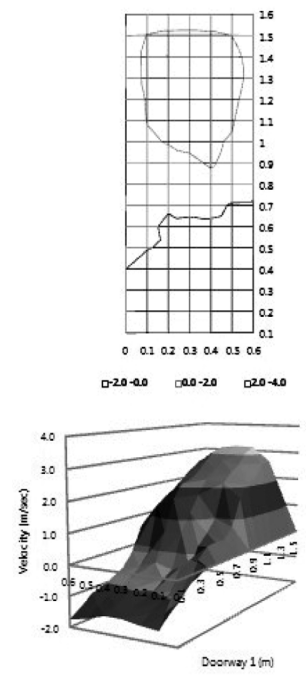

(c)

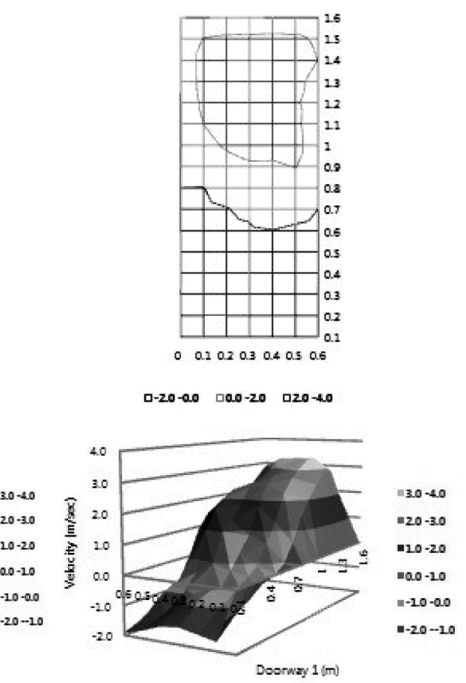

(d)

Fig. 10. Typical results of the pressure contours along the centerline of doorway 1 of width $0.59 \mathrm{~m}$ and height $1.6 \mathrm{~m}$ in $\mathrm{Pa}$ (a) 300 $\mathrm{s}(5 \mathrm{~min}) ;($ b) $600 \mathrm{~s}(10 \mathrm{~min}) ;(\mathrm{c}) 900 \mathrm{~s}(15 \mathrm{~min}) ;(\mathrm{d}) 1200 \mathrm{~s}(20 \mathrm{~min})$

Table 2. Numerical analysis and experiment results ( $M=$ measured by Nakaya et. al, $A=a n a l y z e d$ by FDS)

\begin{tabular}{|c|c|c|c|c|c|c|c|c|c|c|c|c|c|c|c|c|}
\hline \multirow{4}{*}{$\begin{array}{l}\text { Vent } \\
\text { width; } \\
W(\mathrm{~m})\end{array}$} & \multirow{4}{*}{$\begin{array}{c}\text { Heat } \\
\text { release rate } \\
(\mathrm{kW})\end{array}$} & \multicolumn{8}{|c|}{ Burn room } & \multicolumn{7}{|c|}{ Adjacent room } \\
\hline & & \multicolumn{2}{|c|}{$\begin{array}{c}\text { Neutral plane } \\
\text { height; } \\
N_{1}(\mathrm{~m})\end{array}$} & \multicolumn{3}{|c|}{$\begin{array}{c}\text { Mass flow rate } \\
\text { through doorway; } \\
\qquad M(\mathrm{~kg} / \mathrm{sec})\end{array}$} & \multicolumn{2}{|c|}{$\begin{array}{c}\text { Hot layer temp; } \\
T_{r}(\mathrm{~K})\end{array}$} & \multirow{3}{*}{$\begin{array}{c}\text { Hot layer } \\
\text { height; } \\
H_{h_{1}}(\mathrm{~m})\end{array}$} & \multicolumn{2}{|c|}{$\begin{array}{l}\text { Cooling } \\
\text { layer temp; } \\
T_{a_{1}}(\mathrm{~K})\end{array}$} & \multirow{3}{*}{$\begin{array}{c}\text { Hot layer } \\
\text { temp ; } \\
T_{a_{2}}(\mathrm{~K}) \\
\mathrm{A}\end{array}$} & \multicolumn{2}{|c|}{$\begin{array}{c}\text { Neutral plane } \\
\text { height; } \\
N_{2}(\mathrm{~m})\end{array}$} & \multicolumn{2}{|c|}{$\begin{array}{c}\text { Hot layer } \\
\text { height; } \\
H_{h_{2}}(\mathrm{~m})\end{array}$} \\
\hline & & \multirow{2}{*}{ M } & \multirow{2}{*}{ A } & \multirow{2}{*}{ M } & \multicolumn{2}{|c|}{ A } & \multirow{2}{*}{ M } & \multirow{2}{*}{ A } & & \multirow{2}{*}{ M } & \multirow{2}{*}{ A } & & \multirow{2}{*}{ M } & \multirow{2}{*}{ A } & \multirow{2}{*}{ M } & \multirow{2}{*}{ A } \\
\hline & & & & & $M_{g}$ & $M_{a}$ & & & & & & & & & & \\
\hline \multirow[t]{3}{*}{0.29} & 171 & 0.70 & 0.89 & 0.29 & 0.29 & 0.30 & 586 & 479 & 0.54 & 268 & 294 & 369 & 0.97 & 1.47 & 1.35 & 1.38 \\
\hline & 428 & 0.64 & 0.86 & 0.27 & 0.31 & 0.33 & 985 & 618 & 0.62 & 292 & 294 & 410 & 0.92 & 1.30 & 1.35 & 1.26 \\
\hline & 600 & 0.61 & 0.80 & 0.24 & 0.40 & 0.31 & 1267 & 659 & 0.46 & 313 & 295 & 464 & 0.85 & 1.40 & 1.35 & 1.16 \\
\hline \multirow[t]{4}{*}{0.44} & 171 & 0.73 & 0.87 & 0.45 & 0.49 & 0.50 & 514 & 472 & 0.64 & 288 & 295 & 386 & 1.04 & 1.38 & 1.35 & 1.21 \\
\hline & 342 & 0.67 & 0.80 & 0.47 & 0.53 & 0.47 & 746 & 563 & 0.59 & 298 & 294 & 410 & 0.94 & 1.34 & 1.35 & 1.17 \\
\hline & 514 & 0.77 & 0.65 & 0.47 & 0.54 & 0.35 & 867 & 619 & 0.56 & 297 & 295 & 397 & 0.92 & 1.30 & 1.35 & 1.12 \\
\hline & 600 & 0.63 & 0.80 & - & 0.50 & 0.47 & 1035 & 646 & 0.56 & 309 & 294 & 430 & - & 1.30 & 1.35 & 1.12 \\
\hline \multirow[t]{3}{*}{0.59} & 257 & 0.72 & 0.79 & 0.59 & 0.60 & 0.60 & 550 & 500 & 0.59 & 289 & 294 & 393 & 1.02 & 1.30 & 1.35 & 1.19 \\
\hline & 428 & 0.67 & 0.85 & 0.59 & 0.61 & 0.55 & 742 & 581 & 0.51 & 300 & 294 & 415 & - & 1.28 & 1.35 & 1.14 \\
\hline & 600 & 0.65 & 0.85 & 0.58 & 0.57 & 0.54 & 845 & 622 & 0.56 & 303 & 294 & 413 & 0.85 & 1.36 & 1.25 & 1.19 \\
\hline \multirow[t]{3}{*}{0.89} & 257 & 0.75 & 0.85 & 0.80 & 0.79 & 0.77 & 480 & 485 & 0.59 & 237 & 295 & 410 & 1.07 & 1.28 & 1.25 & 1.10 \\
\hline & 514 & 0.68 & 0.78 & 0.81 & 0.84 & 0.81 & 679 & 554 & 0.41 & 299 & 294 & 424 & 0.96 & 1.20 & 1.20 & 1.07 \\
\hline & 600 & 0.66 & 0.80 & 0.79 & 0.87 & 0.78 & 770 & 643 & 0.51 & 303 & 296 & 473 & 0.91 & 1.36 & 1.15 & 1.10 \\
\hline
\end{tabular}

and 0.84 , respectively. According to Table 3 , in the widths of the doorway, for examples, $0.44 \mathrm{~m}$ and $0.59 \mathrm{~m}$, and the heat release rates of 171,257 and $342 \mathrm{~kW}$, the inflow coefficients are from 0.61 to 0.65 . The coefficients are similar to the value, 0.64 , solved by Nakaya et al..

In Eqs. (1), (2), (3) and (4), the temperature of the hot layer in the burn room is constant. Also the temperatures of the cold layer and the hot layer in the adjacent room are constant. But in Eqs. (12) and (13), the temperatures of the hot air layer and the cold layer in the doorway are varied in accordance with height from the floor of rooms. The most important discrepancies between the proposed coefficients and the coefficients by the equations of Nakaya et al. appear to be due to the assumption of the uniform temperature formed in the hot layer of the burn room in spite of stratified fire cases. 
Table 3. Flow coefficients at the burn room doorway

\begin{tabular}{|c|c|c|c|c|c|c|c|c|c|c|c|c|}
\hline \multirow{3}{*}{$\begin{array}{l}\text { Vent width } \\
\text { (m) }\end{array}$} & \multirow{3}{*}{$\begin{array}{c}\text { Energy } \\
\text { Release } \\
\text { Rate(kW) }\end{array}$} & \multirow{2}{*}{\multicolumn{2}{|c|}{$\begin{array}{c}\text { Mass flow rate }(\mathrm{kg} / \mathrm{sec}) \\
\text { by FDS }\end{array}$}} & \multicolumn{9}{|c|}{ Flow coefficient } \\
\hline & & & & \multicolumn{3}{|c|}{ Nakaya et al. } & \multicolumn{3}{|c|}{ Karlsson and Quintiere } & \multicolumn{3}{|c|}{ Proposed in paper } \\
\hline & & outflow & inflow & outflow & inflow & Average & outflow & inflow & Average & outflow & inflow & Average \\
\hline \multirow{3}{*}{0.29} & 171 & 0.29 & 0.30 & 0.77 & 0.56 & 0.67 & 1.02 & 0.69 & 0.86 & 1.14 & 0.63 & 0.89 \\
\hline & 428 & 0.31 & 0.33 & 0.83 & 0.55 & 0.69 & 1.05 & 0.77 & 0.91 & 1.00 & 0.52 & 0.76 \\
\hline & 600 & 0.40 & 0.31 & 1.04 & 0.56 & 0.80 & 1.28 & 0.68 & 0.98 & 1.01 & 0.79 & 0.90 \\
\hline \multirow{4}{*}{0.44} & 171 & 0.49 & 0.50 & 0.97 & 0.65 & 0.81 & 1.20 & 0.92 & 1.06 & 1.04 & 0.88 & 0.88 \\
\hline & 342 & 0.53 & 0.47 & 0.88 & 0.61 & 0.75 & 1.10 & 0.86 & 0.98 & 0.97 & 0.92 & 0.87 \\
\hline & 514 & 0.54 & 0.35 & 0.86 & 0.46 & 0.66 & 1.10 & 0.64 & 0.87 & 0.90 & 0.83 & 0.94 \\
\hline & 600 & 0.50 & 0.47 & 0.87 & 0.57 & 0.72 & 1.09 & 0.77 & 0.93 & 0.90 & 0.85 & 0.96 \\
\hline \multirow{3}{*}{0.59} & 257 & 0.60 & 0.60 & 0.73 & 0.64 & 0.69 & 1.06 & 0.60 & 0.83 & 1.06 & 0.89 & 0.97 \\
\hline & 428 & 0.61 & 0.55 & 0.87 & 0.48 & 0.68 & 1.10 & 0.58 & 0.84 & 1.15 & 0.54 & 0.85 \\
\hline & 600 & 0.57 & 0.54 & 0.78 & 0.45 & 0.62 & 0.98 & 0.58 & 0.78 & 1.02 & 0.90 & 0.96 \\
\hline \multirow{3}{*}{0.89} & 257 & 0.79 & 0.77 & 0.84 & 0.5 & 0.67 & 1.03 & 0.67 & 0.85 & 1.20 & 1.04 & 1.12 \\
\hline & 514 & 0.84 & 0.81 & 0.74 & 0.54 & 0.64 & 0.91 & 0.62 & 0.77 & 0.95 & 0.68 & 0.81 \\
\hline & 600 & 0.87 & 0.78 & 0.79 & 0.48 & 0.64 & 0.97 & 0.60 & 0.79 & 0.94 & 0.88 & 0.91 \\
\hline \multicolumn{4}{|c|}{ Average Value } & 0.84 & 0.54 & 0.70 & 1.07 & 0.69 & 0.88 & 1.02 & 0.80 & 0.91 \\
\hline
\end{tabular}

\section{Conclusions}

When a fire was happened in the two-room's enclosure, the flow coefficients of the inflow and outflow mass rates were analyzed numerically by the FDS. The flow coefficients vary according to fire size and opening configuration. The mean values of the inflow and outflow coefficients are 0.8 and 1.0 respectively. The flow coefficients have usually used for the purpose of compensating the accuracy of the mass flow rates. The inflow and outflow coefficients which are investigated with the FDS, not the flow coefficients, will be inserted in the various mass inflow and outflow rate equations reported by Nakaya and Karlsson.

\section{References}

Bryant, R.A. (2009) The application of stereoscopic PIV to measure the flow of air into an enclosure containing a fire, Exp Fluids, Vol. 47, pp. 295-308.

Chow, W.K. and Zou, G.W. (2005) Correlation equations on fireinduced air flow rates through doorway derived by large eddy simulation, Building and Environment, Vol. 40, pp. 897-906.

Emmons, H.W. (2002) Vent flows, The SFPE Handbook of Fire protection Engineering, NFPA, pp. 32-41.

Forney, G.P. (2008) User's Guide for Smokeview Version 5- A Tool for Visualizing Fire Dynamics Simulation Data, NISTSP 1017 1, National Institute of Standards and Technology.

Guan, H.Y. and Kwok, K.Y. (2009) Computational Fluid Dynamics in Fire Engineering, Butterworth-Heinemann, Burlington.

Jeong, J.Y. and Ryou, H.S. (2002) A study on smoke movement in room fires with various pool fire location, KSME International Journal, Vol. 16, pp. 1485-1496.

Ju, H.D. (2012) Analysis of transient ceiling jet waves in a corridor, $J$. of the Korean Society of Hazard Mitigation, Vol. 11, No. 6, pp. 149-156.
Ju, H.D., Lee, S.B., Jeong, W.B. and Lee, B.H. (2004) Design of an acoustic enclosure with duct silencers for the heavy duty diesel engine generator set, Applied Acoustics, Vol. 65, pp. 441-455.

Karlsson, B. and Quintiere, J.G. (2000) Enclosure fire dynamics, CRC Press.

McGrattan, K., Baum, H., Rehm, R., Mell, W., McDermott, R., Hostikka, S. and Floyd, J. (2009) Fire Dynamics Simulator (Version 5.2) Technical Reference Guide, NISTSP 1018-5, National Institute of Standards and Technology.

McGrattan, K., Klein, B., Hostikka, S. and Floyd, J. (2009) Fire Dynamics Simulator (Version 5.3) User's Guide, NISTSP 10195, National Institute of Standards and Technology.

Nakaya, L., Tanaka, T. and Yoshida, M. (1986) Doorway flow induced by a propane fire, Fire Safety Journal, Vol. 10, pp. 185195.

Prahl, J. and Emmons, H.W. (1975) Fire induced flow through an opening, Combustion and Flame, Vol. 25, pp. 369-385.

Quintiere, J.G. (2006) Fundamentals of fire phenomena, John Wiley $\&$ Sons.

Stavrakakis, G.M. and Markatos, N.C. (2009) Simulation of airflow in one- and two-room enclosures containing a fire source, International Journal of Heat and Transfer, Vol. 52, pp. 2690-2703.

Stekler, K.D., Baum, H.R. and Quintiere, J.G. (1984) Fire induced flows through room openings-flow coefficients, Twentieth Symposium (International) on Combustion/The Combustion Institute, pp. 1591-1600.

Yao, J., Fan, W., Satoh, K. and Kozeki, D. (1999) Verification and application of field-zone-network model in building fire, Fire Safety Journal, Vol. 33, pp. 35-44.

Zukoski, E.E. and Kubota, T. (1980) Two-layer modeling of smoke movement in building fires, Fire and Materials, Vol. 4, No. 1, pp. 17-27.

() 논문접수일 : 2012년 02월 27일

() 심사의뢰일 : 2012년 03월 02일

() 심사완료일 : 2012년 06월 19일 


\section{Nomenclature}

\section{English Symbols}

$C_{d} \quad=$ flow coefficient

$C_{i} \quad=$ inflow coefficient

$C_{o} \quad=$ outflow coefficient

$g=$ gravitational acceleration $\left(\mathrm{m} / \mathrm{s}^{2}\right)$

$H_{h_{1}} \quad=$ height of the boundary between the hot and cold layers at the doorway located between the burn room and the adjacent room (m)

$H_{h_{2}} \quad=$ height of the boundary between the hot and cold layers atthedoorwaylocatedbetweentheadjacentroomandambient $(\mathrm{m})$

$H_{N_{1}} \quad=$ neutral-plane height at the doorway located between the burn room and the adjacent room from the floor $(\mathrm{m})$

$H_{o} \quad=$ doorway height $(\mathrm{m})$

$M \quad=$ molecular weight of the gas $(\mathrm{g} / \mathrm{mol})$

$l=$ number of inflow grids at the $z$ belowneutral-planeheight

$\dot{m} \quad=$ mass flow rate $(\mathrm{kg} / \mathrm{s})$

$\dot{m}_{g} \quad=$ mass outflow rate $(\mathrm{kg} / \mathrm{s})$

$\dot{m}_{a} \quad=$ mass inflow rate $(\mathrm{kg} / \mathrm{s})$

$n \quad=$ numberofoutflowgridsatthezaboveneutral-planeheight

$\bar{p}_{m}(z, t)=$ background pressure $\left(\mathrm{N} / \mathrm{m}^{2}\right)$

$\bar{p}_{m} \quad=$ pressure within $m$-th enclosure $\left(\mathrm{N} / \mathrm{m}^{2}\right)$

$\bar{p}_{0}(z)=$ ambient pressure field $\left(\mathrm{N} / \mathrm{m}^{2}\right)$

$\tilde{p}(\vec{x}, t) \quad=$ flow-induced pressure perturbation $\left(\mathrm{N} / \mathrm{m}^{2}\right)$

$R_{o} \quad=$ ideal gas constant, $8.314 \mathrm{~kJ} /(\mathrm{K} \cdot \mathrm{kmol})$

$T \quad=$ temperature of the gas $(\mathrm{K})$

$T_{a_{1}} \quad=$ temperature of the cold air layer in the adjacent room $(\mathrm{K})$

$T_{a_{2}} \quad=$ temperature of the hot air layer in the adjacent room $(\mathrm{K})$

$T_{r} \quad=$ temperature of the hot air layer in the burn room (K)

$T_{\infty} \quad=$ ambient temperature $(\mathrm{K})$

$W \quad=$ doorway width $(\mathrm{m})$

$\vec{x} \quad=$ spatial co-ordinate $(\mathrm{m})$

$|\Delta p(z)|=$ pressure difference, which is a function of the height $z$ above the neutral-plane $\left(\mathrm{N} / \mathrm{m}^{2}\right)$

\section{Greek Symbols}

$\rho \quad=$ density of the gas $\left(\mathrm{kg} / \mathrm{m}^{3}\right)$

$\rho_{m} \quad=$ background density $\left(\mathrm{kg} / \mathrm{m}^{3}\right)$

$\rho_{m}(z)=$ density as function of height $\mathrm{z}$ from the floor at the doorway in $\mathrm{m}$-th enclosure $\left(\mathrm{kg} / \mathrm{m}^{3}\right)$

$\rho_{\infty} \quad=$ ambient air density $\left(\mathrm{kg} / \mathrm{m}^{3}\right)$

\section{Subscript}

a $\quad=$ surrounding air

$\mathrm{g}=$ gas

$\mathrm{h} \quad=$ layer

i $\quad=$ inflow

$\lim =$ limit

$\mathrm{m} \quad=m$-th enclosure

$\mathrm{N} \quad=$ neutral-plane

o $\quad=$ outflow

$1=$ doorway located between the burn room and the adjacent room

2 = doorway located between the adjacent room and ambient

$\infty \quad=$ ambient 